\title{
Igor Salmič
}

\section{Srečanje sv. Frančiška Asiškega in sultana al-Kamila v Damietti leta 1219 v luči zgodovinskih virov}

\author{
Meeting between Francis of Assisi and Sultan al-Kamil \\ in Damietta in 1219 in the Light of Historical Sources
}

Povzetek: Prispevek umešča srečanje med Frančiškom Asiškim in sultanom al-Kamilom v širši kontekst pete križarske vojne. Predstavljeni so nekateri pisni viri iz 13. stoletja, ki jih lahko razdelimo na notranje in zunanje. Pri prvih so najpomembnejši predstavniki Frančiškovi bratje: Tomaž Čelanski, Bonaventura in drugi, ki pri Frančiškovem namenu obiska izpostavljajo njegovo željo po lastnem mučeništvu in po spreobrnjenju sultana. Zunanji viri, med njimi škof Jakob iz Vitryja in Ernoulova Kronika, pa ob spreobrnjenju sultana poudarjajo tudi iskanje premirja med obema stranema in prost dostop kristjanov do svetih krajev. Proti koncu so izpostavljena nekatera odprta vprašanja glede pravega namena Frančiškovega obiska pri sultanu ter glede njegovega odnosa do križarskih vojn in muslimanov, ob tem pa se ugiba tudi o konkretnih sadovih omenjenega srečanja.

Ključne besede: Frančišek Asiški, al-Malik al-Kamil, Tomaž Čelanski, Bonaventura, Ernoul, križarska vojna

\begin{abstract}
The article places the meeting between Francis of Assisi and Sultan al-Kamil in the wider context of the Fifth Crusade. Some written sources from the 13th century are presented, which can be divided into internal and external. Of the former, the most important representatives are the Franciscan brothers: Thomas of Celano, Bonaventura, and others, who, in terms of Francis' intentions, emphasize his desire for martyrdom and for the conversion of the Sultan. External sources, including Bishop Jacob of Vitry and Ernoul's Chronicle, also emphasize Sultan's conversion but at the same time point out Francis' attempts to gain truce between the two sides and free access of Christians to the holy places. At the end, a few questions are raised about the true purpose of Francis' visit to the Sultan and his attitude to the Crusades and Muslims, along with speculations about the concrete fruits of the meeting.
\end{abstract}

Key words: Francis of Assisi, al-Malik al-Kamil, Thomas of Celano, Bonaventura, Ernoul, Crusade 


\section{Uvod}

Papež Inocenc III. je v uvodnem govoru na četrtem lateranskem koncilu jeseni 1215 z zaskrbljenostjo ugotavljal, da so sveti kraji in s tem tudi Božji grob v Jeruzalemu onečaščeni, ter ponovno - tako kot že dve leti prej v buli Quia maior - pozval kristjane, da je treba osvoboditi Božji grob od sovražnikov križa (Vítores González 2013, 28). Dekret št. LXXI z omenjenega koncila se glasi De recuperanda Terra Sancta in vsebuje norme, spodbude in zapovedi pri organizaciji križarske vojne (Conciliorum Oecumenicorum Decreta 2002, 267-271). Papež sam je bil pripravljen voditi odpravo in se je že napotil proti pristanišču v Genovi, a ga je prehitela smrt v Perugii 16. julija 1216. Honorij III. je sledil predhodnikovim načrtom in leta 1217 izrecno in pod kaznijo izobčenja prepovedal romanja na Božji grob s plačilom davka muslimanom (Vítores González 2013, 29-30).

Peta križarska vojna (1217-1221) je imela torej namen znova osvoboditi Jeruzalem in svete kraje, ki so jih muslimani po začetku križarskih vojn pod Saladinom osvojili leta 1187. Križarje je pod vodstvom jeruzalemskega kralja Janeza iz Brienne in madžarskega kralja Andreja II. pot tokrat vodila skozi Egipt, kjer je za strateški cilj veljalo mesto Damietta. Križarji so se 29. maja 1218 izkrcali na levem bregu rokava delte Nila, tri mesece kasneje pa so zavzeli še stolp pred mestom. Nekaj časa sta si krščanska in muslimanska vojska stali nasproti. Poleti 1219 je bilo nekaj silovitih bitk z ogromno žrtvami na eni in drugi strani, a do kakšnega odločilnega preboja ni prišlo. Sprva je kazalo, da bodo križarji zlahka premagali nasprotnike, a je muslimanski svet prihitel na pomoč egiptovskemu sultanu al-Maliku al-Kamilu in odbil križarje ter jim 29. avgusta zadal hud udarec, ki je pri slednjih terjal 6000 žrtev. Takrat sta se obe strani dogovorili za začasno premirje, ki je trajalo do 26. septembra 1219. V tem vmesnem času je sultan križarjem dvakrat ponudil mir ter jim obljubil vrnitev Jeruzalema v zameno za njihov umik iz Egipta. Jeruzalemski kralj in drugi krščanski vojskovodje so bili predlogu naklonjeni, ne pa tudi papežev odposlanec kardinal Pelagij Galvan, ki je želel nadaljevati boje, trdno prepričan v vojaško zmago krščanske vojske. (Sella 2005, 488-489, 494; Ligato 2011, 435) Tako so križarji 5. novembra 1219 končno osvojili Damietto, kasneje pa še dodatna ozemlja z željo, da bi prišli tudi do Kaira, a jim to ni uspelo. Leta 1221 so se morali po številnih izgubah umakniti tudi iz Damiette (Vauchez 2010, 98). 
Al-Kamil je pogosto iskal kompromise s kristjani. Jasen dokaz tega je bilo desetletno premirje (1229-1239), ki ga je v Jafi podpisal s cesarjem Friderikom II. S tem premirjem so kristjani ponovno dobili v roke Jeruzalem (z izjemo Tempeljskega griča z mošejami), Betlehem in Nazaret (Lehmann 2012, 514; Vítores González 2013, 31-33; Vauchez 2010, 90-91, 98-99). Kot bomo videli v nadaljevanju, je v dogajanje pete križarske vojne v veliki meri posegel tudi sv. Frančišek Asiški.

\section{Teološko-kulturni kontekst odnosov med krščanstvom in islamom v srednjem veku}

Preden se pobliže dotaknemo srečanja med Frančiškom Asiškim in sultanom al-Kamilom, se zdi primerno ta dogodek umestiti v širši zgodovinski kontekst kompleksnih odnosov med krščanstvom in islamom v srednjem veku.

Koliko so zahodni kristjani pravzaprav poznali islam? V nasprotju s krščanskim Vzhodom, ki je bil v stalnem stiku z muslimanskim svetom vse od 7. stoletja naprej, na Zahodu podobne izkušnje niso imeli. Za izjemo lahko štejemo Iberski polotok, kamor so muslimani prispeli v začetku osmega stoletja in do leta 1492 ohranili še zadnjo trdnjavo v Granadi. Deloma lahko omenimo tudi južno Italijo, predvsem Sicilijo, kjer so bili muslimani močno navzoči od sredine osmega do sredine desetega stoletja. Že davno predtem je nadaljnje širjenje islama po Evropi ustavil Karel Martel v bitki pri Poitiersu leta 732 .

Večina evropskega prebivalstva je o islamu vedela zelo malo, zato ni manjkalo predsodkov, napetosti in tudi sovraštva. Koran je bil sicer v latinščino preveden leta 1140, a je bil na razpolago le redkim. Po drugi strani zaznamo tudi vzajemno sobivanje in sodelovanje kristjanov in muslimanov. To je razvidno npr. v umetnosti pa tudi v srednjeveški filozofiji. Sholastika je pogosto uporabljala velike muslimanske avtoritete. Tako je npr. Tomaž Akvinski (1225-1274) v Summa Theologiae z naklonjenostjo navajal razne arabske filozofe in razlagalce Aristotela, predvsem Avicenna in Averroesa, Rajmund Lull (1232-1316) pa je svoja dela o duhovnosti in mistiki dopolnil z zavzetim študijem islamske misli (Tanner 2013, 211-212). Kljub tem povezavam pa ni bilo zadostnega poznavanja islama samega. Mnogim 
srednjeveškim kristjanom se namreč islam ni predstavljal kot nova religija, temveč bolj kot nepopolna oz. heretična oblika krščanstva (Tanner 2013, 67; Vauchez 2010, 96, 100). Krščanska stran zato ni imela za nalogo zgolj spopada $z$ »neverniki«, temveč je bila prežeta predvsem z željo po spreobrnjenju muslimanov in njihovem spoznanju prave vere, ki jo je predstavljalo krščanstvo. V tem duhu so bile tudi križarske vojne, katerih začetek sega v leto 1095, mišljene kot sredstvo, s pomočjo katerega bi muslimani lahko slišali krščansko oznanilo. (Vauchez 2010, 100)

V istem obdobju, torej na prehodu iz 12. v 13. stoletje, je tudi znotraj krščanstva zaznati veliko novosti. Če so bila prejšnja stoletja zaznamovana z meniškim načinom življenja v smislu oddaljitve od sveta (fuga mundi), pa so se zdaj začela prebujati mnoga laiška gibanja, ki so stremela po oznanjevanju Božje besede širšim množicam s poudarkom na pokori in ubožnem načinu življenja. Stabilnost kraja, značilna za pretekla stoletja, je predala primat potujočim pridigarjem. Nekateri avtorji trdijo, da se je ravno v 12. oz. 13. stoletju, ko zaznamo velik ekonomski razvoj ter povečanje neenakosti, ponovno začel prebujati tudi evangelij (Vauchez 2010, 42). Frančišek Asiški se s svojimi sobrati uvršča v ta živi tok duhovnih gibanj tedanjega časa. Tudi zanje je bila ena od značilnosti potujoče oznanjevanje evangelija, in to ne samo v domačih krajih, temveč tudi onkraj meja. To namero jasno potrjuje generalni kapitelj leta 1217, ko se sprejmeta dve pomembni odločitvi za prihodnost reda: ustanovitev provinc ter pošiljanje bratov onkraj meja Italije. Nekateri gredo proti severu v Nemčijo in na Madžarsko, drugi pa proti vzhodu, med drugim tudi v Sveto deželo. Za brate je to pomenilo veliko novost, saj je s prečkanjem Apeninskega polotoka red potrdil univerzalni značaj svojega sporočila in namere, da se to isto sporočilo prinese vsemu tedaj znanemu svetu. (Vauchez 2010, 86-87) V tej luči lažje razumemo tudi željo Frančiška Asiškega, da bi oznanjal evangelij med muslimani.

\section{Frančišek Asiški in muslimani}

Muslimanski svet je asiškega ubožca pritegnil že zelo zgodaj. Leta 1212 se je Frančišek skušal odpraviti v Sirijo, a so ga vetrovi ponesli na dalmatinsko obalo (1 Cel 55: Fonti Francescane /FF/ 418; Čelanski 2014, 74-75). Podobno je bilo leta 1213, ko je želel v Maroko, pa mu je načrte prekrižala bolezen v Španiji (1 Cel 56: FF 420). V tretje, leta 1219, mu je končno uspelo. 
To leto so se bratje na generalnem kapitlju pri cerkvi Marije Angelske pri Assisiju odločili, da pošljejo brate v Tunizijo in Maroko. Da bi dal dober zgled - tako poroča Jordan iz Giana v svoji Kroniki (Kronika 10: FF 2332) se je Frančišek podal v Egipt. Z nekaterimi brati se je 24. junija 1219 vkrcal na eno izmed ladij v Anconi, ki so prevažale materialne zaloge in drugo pomoč križarjem v Damietto. Križarji so bili namreč že dobro leto nastanjeni v tej pomembni bazi. Frančišek je najprej pristal v Akri v Siriji, v Egipt pa prispel julija 1219. Križarje naj bi želel prepričati v premirje, ki ga je s konkretnimi predlogi ponudil al-Kamil, a kot smo že omenili, je temu nasprotoval kardinal Pelagij (Lehmann 2012, 514). Frančišek je tudi sam želel srečati sultana, a mu na začetku to ni bilo omogočeno. Šele po 29. avgustu, ko so križarji utrpeli hud poraz in sprejeli začasno premirje, je kardinal Pelagij po začetnem nestrinjanju in dvomu asiškemu ubožcu na koncu le dovolil obisk pri sultanu. Frančišek pa se v sultanov tabor ni odpravil sam, ampak je s seboj vzel brata Iluminata (Bonaventura, LegM IX 8,1: FF 1173).

\section{Frančiškov obisk pri sultanu v luči »notranjih" virov}

Zgodovinsko srečanje med Frančiškom Asiškim in egiptovskim sultanom al-Malikom al-Kamilom (sultan je postal leta 1218) lahko natančno časovno umestimo, in sicer med 29. avgust in 26. september 1219, ko je med krščansko in muslimansko stranjo vladalo začasno premirje. O samem srečanju v Damietti imamo na razpolago veliko virov iz istega stoletja, ki pa med seboj niso najbolj usklajeni in je zato iz te množice težko izluščiti realno podobo. Še več, ponekod se zdi, da so si opisi celo nasprotujoči, kot zatrjuje Leonhard Lehmann $(2012,513)$. Vire lahko na splošno razdelimo v dva sklopa: na eni strani imamo uradne biografije o Frančišku, ki so jih napisali Frančiškovi sobratje (notranji viri), po drugi strani pa zapise avtorjev, ki niso pripadali redu manjših bratov (zunanji viri) in ki so zaradi neobremenjenega pisanja po mnenju mnogih zgodovinarjev bolj verodostojni. Tako npr. Franco Cardini zatrjuje, da ravno ti zunanji viri potrjujejo, da je do tega zgodovinskega srečanja med Frančiškom in sultanom resnično prišlo $(2019,38)$.

Najprej se ustavimo ob notranjih, frančiškovskih virih. Na prvem mestu je treba omeniti Tomaža Čelanskega, prvega uradnega biografa asiškega 
ubožca, ki je v letih 1228-1229 spisal Vita beati Francisci (Življenje svetega Frančiška). Poleg njega pa so tukaj še Julijan iz Speyerja, Jordan iz Giana ter Bonaventura.

Mnogi avtorji navajajo namen, ki je gnal Frančiška v srečanje $\mathrm{z}$ al-Kamilom. Tomaž Čelanski, Julijan iz Speyerja, še bolj pa Bonaventura močno izpostavljajo Frančiškovo željo po mučeniški smrti. Čelanski že ob prvem Frančiškovem poskusu leta 1212, ko se je odpravljal v Sirijo, zapiše: »V šestem letu od svojega spreobrnjenja je silno gorel v hrepenenju po svetem mučeništvu in je hotel odpluti v sirske kraje." (1 Cel 55: FF 418; Čelanski 2014, 74) Ob obisku sultana leta 1219 in ob vsebini njunega srečanja pa isti avtor zaključi: „V vsem tem pa Gospod ni izpolnil njegovega hrepenenja [po mučeništvu] in mu je prihranil prednost posebne milosti.« (1 Cel 57: FF 423; Čelanski 2014, 77) Pri Čelanskem ima hrepenenje po mučeništvu posebno mesto, saj ga ima po vzoru Jezusovih učencev za vrhunec apostolskega življenja. Bonaventura vse to utemeljuje še bolj teološko: "Z žarom ljubezni je želel posnemati slavo in zmago svetih mučencev [...] Vžgan s to popolno ljubeznijo, ki odžene strah (1 Jn 4,18), se je želel tudi on kot živa hostija darovati Gospodu v ognju mučeništva, z namenom, da bi se oddolžil Kristusu, ki je umrl za nas, ter da bi druge nagovoril za Božjo ljubezen. V šestem letu od svojega spreobrnjenja se je vžgan z željo po mučeništvu odločil, da bo odplul proti Siriji, da bi tam oznanjeval krščansko vero in pokoro Saracenom in drugim nevernikom." (LegM IX,5: FF 1169-1170) V opisu srečanja s sultanom leta 1219 je Bonaventura spet izpostavil to željo: »Frančišek [...] se je odločil, da bo poskusil s podvigom, brez strahu pred smrtjo, temveč celo z željo po njej.«(LegM IX,7: FF 1172) Isti avtor ob tem srečanju uporablja tudi evangeljske podobe ovc in volkov (Mt 10,16). Poleg mučeništva je pri Bonaventuri prisoten še drug namen: Frančišek je srečal sultana, »da bi pokazal njemu in ljudstvu pot odrešenja in da bi oznanjal evangelij resnice«(LegM IX,8: FF 1174). Ko ga je sultan prosil, naj ostane pri njem, mu je Frančišek odgovoril: „Če se boš ti in ljudstvo spreobrnilo h Kristusu, bom iz ljubezni do Njega rad ostal z vami.» (LegM IX,8: FF 1174) Tu gre torej za željo po spreobrnjenju sultana. V ta namen je Bonaventura dodal še en zanimiv detajl, ki ga ne najdemo pri Čelanskem, namreč preizkus z ognjem (ordalium - Božja sodba). Z njim je Frančišek želel izzvati sultanove duhovnike o tem, katera je prava vera, in jih zato povabil, naj skupaj z njim stopijo v plamen ognja. Sultan in njegovi duhovniki tega izziva niso hoteli sprejeti. (LegM IX,8: FF 1174) Gre 
za prakso, ki jo poznamo pri preroku Eliju v Stari zavezi, ko izzove poganske duhovnike (1 Kr 18,20-40), in pri preroku Danijelu, ko s tovariši pride nepoškodovan iz peči (Dan 3,19-30). Bonaventura je imel pri prikazovanju Frančiškove podobe skozi stoletja večji vpliv od Tomaža Čelanskega ${ }^{1}$ (Lehmann 2012, 517-518), in to je razvidno tudi pri Frančiškovem srečanju s sultanom. Bonaventura je s svojim opisom tako močno zaznamoval kasnejše generacije, da so skorajda vsi slikarji od Giotta naprej ob srečanju Frančiška s sultanom upodabljali tudi ogenj. Ognja pa npr. ni videti na najstarejši znani upodobitvi omenjenega srečanja, ki ga je leta 1240 naslikal Coppo iz Marcovalda in se nahaja v kapeli Bardijev v cerkvi sv. Križa v Firencah (San Francesco e il sultano 2019, 14). Avtor je seveda sledil pripovedi Čelanskega - v kateri ni sledu o ognju - saj gre za čas, ko njegov življenjepis še ni bil prepovedan.

Kar se tiče samega preizkusa z ognjem, je težko dokazati njegovo zgodovinskost. Po eni strani se ta praksa ne zdi v soglasju z miroljubnim značajem svetega Frančiška, po drugi strani pa je tudi že omenjeni IV. lateranski koncil v dekretu 18 prepovedal to prakso (Conciliorum Oecumenicorum Decreta 2002, 244). Razloga sta vsaj dva: 1) da ne bi na predrzen način skušali Boga in ga vključevali v zgolj človeške procese; 2) neutemeljenost takih praks iz preteklosti in tudi smrt nedolžnih (Frugoni 2011, 530). Nekateri skušajo to prakso povezati z Mohamedom, ki naj bi na podoben način izzval kristjane v Medini (Vítores González 2013, 38). Lehmann na podlagi analize 16. poglavja Frančiškovega Nepotrjenega vodila iz leta 1221, ki govori o miroljubnem misijonu Frančiškovih bratov med muslimani (Saraceni), zavrača zgodovinsko resničnost preizkusa z ognjem (Lehmann 2012, 540-552). K temu besedilu se bomo na kratko še vrnili.

Od Tomaža Čelanskega in Bonaventura se razlikuje pripovedovanje Jordana iz Giana, ki je osnoval Frančiškov red v Nemčiji. V njem ni besede o hrepenenju po mučeništvu in o preizkusu z ognjem niti o tem, da je

1 Glavni razlog je to, da je bil leta 1263 Bonaventurov življenjepis Legenda maior razglašen za uradnega, tri leta kasneje pa se je vodstvo reda z namenom poenotenja podobe sv. Frančiška in posledično tudi enotnosti reda odločilo uničiti vse druge predhodne življenjepise, torej tudi življenjepis Tomaža Čelanskega, ki so ga po naključju ponovno odkrili šele leta 1768. Podobno usodo so doživeli tudi drugi življenjepisi, ki so ponovno ugledali luč sveta med 19. in 20. stoletjem. A odkritjem še ni videti konca: leta 2015 je francoski zgodovinar Jacques Dalarun odkril skrajšani Frančiškov življenjepis, ki ga je sestavil ravno Tomaž Čelanski in ki ga poznamo pod imenom Vita ritrovata del beatissimo Francesco (Najdeni življenjepis svetega Frančiška). 
sultan z veseljem prisluhnil asiškemu ubožcu in ga občudoval, kot sta to poudarjala Čelanski in Bonaventura. Jordan iz Giana kot razlog potovanja k sultanu izpostavlja Frančiškov dober zgled in ljubezen do Kristusovega trpljenja. Na koncu mirno doda, da Frančišek pri sultanu ni dosegel želenih sadov in da se je zato odločil, da se od njega poslovi. (Kronika 10: FF 2332) Tukaj ni prisoten noben triumfalizem. Med tremi omenjenimi viri se Lehmannu zdi ravno Jordanova pripoved najbolj verodostojna, saj naj bi odsevala Frančiškov način razmišljanja o misijonu z dobrim zgledom ter o ljubezni do Kristusovega trpljenja. Tudi sam sultan je označen pozitivno: ni ovrednoten kot »divja zver", ampak kot prijateljski gostitelj. Jordan iz Giana ne zavrača vrednosti mučeništva, a ga vidi kot posledico vere in zvestobe Kristusu, ne pa kot nekaj, kar je treba iskati, kot je bilo v primeru Berarda in tovarišev v Maroku skorajda istočasno, leta 1220. (Lehmann 2012, 519-521) O slednjih ni prezreti kritične Jordanove opazke (Kronika 8: FF 2330).

\section{Frančiškov obisk pri sultanu v luči »Zunanjih" virov}

Jordan iz Giana je neke vrste most med notranjimi (Čelanski, Julijan, Bonaventura) in zunanjimi viri. K slednjim moramo najprej prišteti škofa Jakoba iz Vitryja (1170-1240), ki je bil leta 1216 posvečen v škofa v Akri (Akkonu) in je od blizu spremljal dogajanje v Damietti. V svojem pismu iz leta 1220 omenja, kako je Frančišek nekaj dni pridigal Saracenom, a z malo uspeha. Kljub temu ga je sultan na skrivaj prosil, naj moli zanj, da bi sprejel tisto vero, ki bi bila Bogu všeč (2 Vitry 2: FF 2212). V njegovem drugem delu Historia Occidentalis/Orientalis, napisanem med letoma 1221 in 1226, je podan daljši opis z zanimivo novostjo: sultan je v strahu pred tem, da bi kdo izmed njegove vojske prešel v krščanstvo, prosil Frančiška, naj odide (Vitry Hoc 14: FF 2227). V nasprotju s prejšnjimi pripovedovalci se lahko Jakob pohvali s tem, da se je tudi osebno srečal s Frančiškom. Jakob bolj kot drugi dosedanji pripovedovalci pri Frančišku izpostavlja, čeprav bolj posredno, željo po miru, ki ga je s svojo držo oznanjal tudi pri sultanu (Lehmann 2012, 523).

Drugi zunanji vir je Ernoulova Kronika, zapisana med letoma 1227 in 1229. Gre za delo Francoza, ki je na Vzhodu bival že od konca 12. stoletja. Pri opisu omenjenega srečanja, ki je občutno daljši od drugih, ne omenja nasilja 
Saracenov, ko so prijeli Frančiška, kot je to kasneje opisoval Bonaventura. Poimensko ne govori o Frančišku, temveč o »dveh klerikih«, ki sta odšla med Saracene. Motiv, ki vleče Frančiška k sultanu, ni mučeništvo, temveč skrb za odrešenje sultanove duše, torej njegovo spreobrnjenje, kar omenja že Bonaventura. Dodan je še en nov detajl: Frančišek in Iluminat sta pokazala pripravljenost na teološko debato s sultanovimi duhovniki. Sultan skliče nekatere svoje dostojanstvenike, da bi jih vprašal za nasvet: ti mu predlagajo, naj ne prisluhne kristjanoma, saj to prepoveduje zakon. Še več, kdor pridiga proti njihovemu zakonu, mora biti obglavljen. Sultan ostane sam z gostoma, napravi izjemo in ju ne da usmrtiti. Povabi ju, naj ostaneta, a sta Frančišek in sobrat odšla, ker jima niso dovolili pridigati. Hotel ju je tudi obdariti, a sta želela le nekaj hrane, preden sta se odpravila na pot. (Ernoul 37,1-4: FF 2231-2234) Zelo podoben je opis t. i. Bernarda Zakladnika (Tesoriere), ki je v svojem delu prav tako navajal pravkar omenjeno Ernoulovo delo. Zanimiv je opis sultana, saj je ta označen kot »človek milega srca». O ognju ni nobenega sledu (Tesoriere 1-3: FF 2235-2237). Lahko omenimo še Eraklijevo Kroniko iz let 1229-1231, delo neznanega francoskega avtorja. Kratek opis o Frančišku prinaša tri poudarke, ki jih drugod nismo našli: 1) Frančišek ostane v Damietti, dokler je ne zavzamejo križarji; 2) od tam odide zaradi nemoralnega ravnanja krščanske vojske; 3) ustavi se tudi v Siriji (Eraklij: FF 2238; Lehmann 527).

Pri zunanjih virih je srečanje Frančiška s sultanom predstavljeno bolj podrobno kot pri notranjih virih in tudi sam sultan je (razen pri Jakobu iz Vitryja) predstavljen zelo pozitivno. V nobenem izmed njih ni govora o hrepenenju po mučeništvu, ampak bolj o spreobrnjenju, koncu vojne in tudi miru. Zgodovinarji se najdlje ustavljajo ob Ernoulu in njegovi zagonetni besedni zvezi »veliko dobro delo«. Avtor namreč podrobno opiše Frančiškov dialog s papeževim odposlancem kardinalom Pelagijem, pri katerem zatrjuje, da želi s sobratom k sultanu z namenom, da bi tam opravila "veliko dobro delo«. Kaj te besede pomenijo? Mučeništvo, sultanovo spreobrnjenje, mir? Nekateri avtorji so mnenja, da te besede predstavljajo zagotovilo, da bi lahko Frančiškovi bratje in kristjani znova svobodno, brez plačevanja davkov, romali v Jeruzalem in na Božji grob (Sella 2005, 493494; 2011, 499). To tezo potrjuje tudi pričevanje manjšega brata spirituala Angela Klarena (ok. 1255-1337), ki je v svoji Knjigi kronik zapisal, da je sultan Frančišku in bratom omogočil prost dostop, brez plačila davkov, do Božjega groba (Libro delle Cronache, Prologo: FF 2154). Lehmannu 
se ta razlaga ne zdi prepričljiva. Po njegovem mnenju "veliko dobro delo« ne predstavlja svobodnega romanja kristjanov k Božjemu grobu, ker o tem ni nikjer eksplicitnega govora. Frančišku naj bi bolj šlo za dogovor, spravo in mir med obema stranema. To naj bi ustrezalo tudi Frančiškovemu oznanilu pokore in miru, ki ga je povsod živel in širil. To naj bi bilo razvidno tudi iz že omenjenega 16. poglavja Nepotrjenega vodila iz leta 1221, ki govori o delovanju bratov med Saraceni (muslimani) in drugimi neverniki in ki je sad Frančiškove osebne izkušnje bivanja med muslimani: »Bratje, ki bodo šli, lahko med neverniki duhovno bivajo na dva načina. Prvi način je ta, da ne povzročajo prepirov in prerekanj; 'podvržejo naj se marveč vsaki človeški ustanovi' (1 Pt 2,13) in priznajo, da so kristjani. Drugi način pa je ta: ko bodo videli, da je Gospodu všeč, naj oznanjajo Božjo besedo, da bi začeli verovati v vsemogočnega Boga, Očeta in Sina in Svetega Duha, Stvarnika vesolja, Sina Odrešenika in Zveličarja, in da bi se dali krstiti in bi postali kristjani, kajti 'če se kdo ne prerodi iz vode in Svetega Duha, ne more vstopiti v Božje kraljestvo’ (Jn 3,5).«(Vodilo in življenje 1998, 108)

V besedilu je najprej poudarjena drža majhnosti, preprostosti, bratske sloge in sprave z drugimi, potem pa tudi konkretno oznanilo. Po Lehmannovem mnenju Frančiškovo oznanjevanje miru med ljudstvi in religijami ni nekaj dodanega, ampak je samo bistvo njegovega apostolata (2012, 550-551). Podobno razmišlja tudi Hoeberichts: po njegovem Frančiškovi bratje ne gredo k Saracenom, da bi trpeli in bili preganjani, temveč da bi jim prinesli pravi mir s ponižnim služenjem in tako pokazali pravi obraz krščanstva $(2002,199-200)$.

Bežno omenimo še nekatere druge vire, ki pa jih moramo zaradi pomanjkljive zgodovinske verodostojnosti jemati z rezervo, npr. Rožice svetega Frančiška iz 14. stoletja. V njih je med drugim zapisano, da je sultan celo sprejel krščanstvo in se dal kasneje tudi krstiti (I Fioretti, XXIV. poglavje: FF 1855-1856). Poznamo še zgodovinski falsifikat pod imenom Verba fratris Illuminati socii b. Francisci ad partes Orientis et in conspectu soldani Aegypti s konca 13. oz. začetka 14. stoletja, v katerem Frančišek pred sultanom opravičuje križarsko vojno in jo podpira (Ricordi di frate Illuminato: FF 2690-2691). To besedilo je bilo kasneje v pomoč mnogim pridigarjem, saj jim je služilo kot osnova za utemeljevanje svete vojne (Sella 2011, 504-506; Jeusset 1996, 190). 
Če povzamemo, je torej zaznati, da imajo notranji viri težavo pri predstavljanju Frančiška, ki je odšel od sultana »brez vidnega uspeha«, in zato poskušajo zgodbo obogatiti s kakšnim čudežem (preizkus z ognjem) ali z željo po mučeništvu, ki je bila na drugačen način uslišana kasneje ob prejemu svetih ran na gori La Verna (Lehmann 2012, 530-531). Na podlagi zunanjih virov pa lahko zaključimo, da so bili glavni motivi Frančiškovega obiska pri sultanu njegovo spreobrnjenje, svoboden dostop do Jeruzalema in oznanilo miru.

Frančišek je z obiskom sultana pustil sledi tudi v muslimanskem zgodovinopisju. O omenjenem srečanju naj bi pričal Fakhr al-Din Muhamad ibn Ibrahim al-Fârisî, sultanov duhovni svetovalec. Umrl je leta 1224 in je pokopan na pokopališču Qarafa v Kairu. Na njegovem nagrobnem kamnu piše: "Ta ima vrlino, ki jo vsi poznajo: svoje dogodivščine z Malik al-Kamilom in vse to, kar se mu je zgodilo zaradi zelo znanega meniha (rahib)«.V njegovi biografiji iz 15. stoletja pa je zapisano, da je imel "znamenit dogodek" z neimenovanim rahibom. Kaj točno bi to pomenilo, je težko reči. Nekateri vlečejo vzporednice z Bonaventurom, ki govori o preizkusu z ognjem. Z gotovostjo pa Sella zatrjuje, da ta islamski vir potrjuje močno razpravo med Frančiškom in muslimanskimi učenjaki pred sultanom. (Sella 2011, 497-498; 2005, 491) Tako je tudi muslimanski svet Frančiška ohranil v spominu, čeprav je treba priznati, da je ta spomin počasi zbledel in je bil znova obujen šele sredi 20. stoletja.

\section{Nekatera odprta vprašanja}

Mnogi avtorji postavljajo pod vprašaj Frančiškovo željo po mučeništvu (Lehmann 2012, 521). Zdi se jim, kot že rečeno, da sta Tomaž Čelanski in Bonaventura hotela Frančiškov neuspeh, ko je od sultana odšel praznih rok, "pokriti« z veličastnimi elementi, kot so čudeži in želja po mučeništvu. Pri njiju naj ne bi bilo prostora za neuspeh in polomije (Lehmann 2012, 530). Bolj sta do mučeništva prizanesljiva André Vauchez in Mary Melone. Vauchez Frančiškove želje po mučeništvu ne izključuje, saj naj bi ta predstavljala njegov način razmišljanja, ki je bil tipičen za njegovo obdobje in kulturo, ko se je pogosto sklicevalo na apostole, ki so želeli do konca slediti Jezusu. Krona vsega tega je bilo vsekakor darovanje lastnega življenja. (2010, 95-96) Melonova pa v svojem zanimivem prispevku pod 
naslovom Il desiderio di martirio di Francesco d'Assisi nella Legenda maior di Bonaventura di Bagnoregio natančno analizira in prikaže Bovaneturovo teologijo in njegov pogled na mučeništvo, pri katerem v ospredju ni želja po samem mučeništvu kot takem, ampak gre za povezanost tega hrepenenja z ljubeznijo, ki je temelj vsakega resničnega darovanja. (2011, 509-524)

Omenili smo tudi spreobrnjenje in mir, zato si lahko zastavimo vprašanje: Ali sta si oznanjevanje miru in želja po spreobrnjenju v nasprotju ali ne? Ali je mogoče, da je Frančišek želel spreobrniti sultana in njegovo ljudstvo ter tako doseči medsebojni mir? Spreobrnjenje kot pot do miru je prisotno pri nekaterih avtorjih. Luciano Radi npr. zatrjuje, da je Frančišek želel spreobrniti muslimane $z$ namenom, da bi od njih pridobil pravico do miroljubnih romanj na svete kraje (Lehmann 2012, 521, op. 35; Radi 2006, 38). Pauli Annala gre še korak dlje s trditvijo, da ob sultanovem spreobrnjenju ne bi bilo več razloga, da bi se kristjani in muslimani bojevali, saj bi se na ta način mir ponujal sam po sebi (Lehmann 2012, 528, op. 48; Annala 2003, 409-425). Če sprejmemo to razmišljanje, potem bi lahko na nov način interpretirali tudi 16. poglavje Frančiškovega Nepotrjenega vodila: ker ni prišlo do spreobrnjenja od zgoraj (od sultana do ljudstva), naj bi kasneje Frančišek spremenil "taktiko« in bratom zapovedal, naj z miroljubno in nevsiljivo držo oznanjujejo evangelij pri preprostih ljudeh (misijon od spodaj), kot je to zapisano v besedilu. Te interpretacije ne najdemo pri Lehmannu, ki je podrobno analiziral omenjeno poglavje, in tudi avtor teh vrstic nima na razpolago dokazov oz. indicev za to trditev. Lahko pa morda služi kot izziv in hkrati vabilo za nadaljnje študije o tej tematiki.

Glede motiva spreobrnjenja pa je zelo kritičen Pacifico Sella. Sprašuje se, kako je možno, da bi se Frančišek odpravil k sultanu z namenom, da bi ga spreobrnil, če pa so istočasno kristjani hoteli z mečem osvojiti Damietto in uničiti egiptovski sultanat. Če bi bilo tako, potem bi po njegovem mnenju tudi sam Frančišek deloval kot nekdo, ki ne zna trezno presoditi resničnega stanja dogodkov. (Sella 2011, 495)

Kot je razvidno, se mnogi avtorji ubadajo z odnosom med spreobrnjenjem in oznanjevanjem miru. Je pa vprašanje miru zanimivo še z enega vidika, in sicer v povezavi odnosa Frančiška do križarske vojne. Je bil Frančišek proti križarskim vojnam, kot jih je zasnovala tedanja Cerkev, ali ne? Gre pri tem za prelom ali za sobivanje? Nekateri avtorji brez dlake na jeziku 
zatrjujejo, da je Frančiškov način oznanjevanja evangelija v nasprotju z metodami takratne hierarhične Cerkve (Vítores González 2013, 30-31). Frančišek je namreč zagovarjal spoštovanje vsake človeške ustanove, oznanjevanje miru z bratsko slogo in ponižnostjo. V tej luči je želel, da so bratje podvrženi vsaki človeški ustanovi, torej tudi muslimanom, križarji pa so si, nasprotno, hoteli Saracene podvreči (Lehmann 2012, 545). Močno diskontinuiteto med Frančiškom in križarskimi metodami zagovarja tudi Alfonso Marini. Na podlagi Frančiškovih spisov, pri katerih je v ospredju oznanjevanje miru in dialoga z vsemi (tudi z muslimani), avtor ugotavlja, da bi Frančišek s svojo držo težko legitimiral križarske metode, zato je zelo verjetno zavračal sveto vojno (2012, 44-53).

Nekateri drugi zgodovinarji so do križarskih vojn bolj prizanesljivi. Franco Cardini npr. zatrjuje, da si Frančišek v času, ko pravni in institucionalni vidik njegovega reda še ni bil čisto razjasnjen (IV. lateranski koncil je prepovedoval ustanavljanje novih redov), ni mogel kratko malo privoščiti, da bi se zoperstavil hierarhičnemu pristopu pri križarskih vojnah. V nasprotnem primeru bi spravil v nevarnost sam obstoj »svojega« reda. Skratka, Frančišek po njegovem mnenju ni delal proti križarjem in tudi ne brez dovoljenja križarjev. $(2019,38)$ Podobnega mnenja je Vauchez, ki navaja zanimiv razlog, zakaj Frančišek ni nastopil a priori proti križarskim vojnam: križarska vojna je bila cerkvena institucija, ki jo je spodbudilo papeštvo, s katerim je bil red manjših bratov od samega začetka zelo povezan. Ne smemo niti pozabiti, da križarska vojna na začetku 13. stoletja ni pomenila verske vojne oz. neke vrste kolonialne odprave, temveč je bila predvsem spokorno, čeprav oboroženo romanje, katerega cilj sta bila obramba in ponovno zavzetje svetega mesta Jeruzalem, da bi romarjem omogočili prost dostop do svetih krajev. Frančišek naj zato ne bi nasprotoval križarskim pohodom, temveč naj bi iz njih črpal in uresničil globok čut po iskanju bratstva med zahodnimi in vzhodnimi kristjani, kjer naj bi svoje mesto imeli tudi muslimani in judje. (Vauchez 2010, 99-100; Sella 2005, 487-488, 495; Tolan 2011, 553) Končno pri Frančišku ni nobene obsodbe križarskih pohodov, ker naj bi sam deloval na neki drugi, vzporedni ravni, ko je oznanjeval evangelij, ki pa ni v nasprotju s križarskimi metodami.

V vsakem primeru, bodisi se strinjamo s to ali ono interpretacijo, pa pri Frančišku vendarle opazimo neko novost v odnosu do muslimanov. Gre namreč za prvega redovnega ustanovitelja, ki je v Vodilo dal zapisati 
organiziran način oznanjevanja med tistimi, ki so zunaj krščanskega sveta, torej med muslimani (Lehmann 2012, 552). Vauchez je to lepo formuliral na naslednji način: »Frančišek je prvi krščanski svetnik srednjega veka, ki je iskal stike z muslimanskim svetom in jih tudi našel.« $(2010,89)$ Nekateri redovi pred Frančiškom so sicer že tkali stike z muslimanskim svetom, vsaj od začetka prvih križarskih pohodov ob prehodu iz 11. v 12. stoletje. Tako npr. že vodilo trinitarijcev iz leta 1198 govori o Saracenih. A istočasno je treba poudariti, da neposredni naslovniki pri slednjih niso muslimani, temveč kristjani, ki so živeli na muslimanskih področjih in ki so jim trinitarijci nudili duhovno in materialno pomoč. Frančišek pa se po drugi strani obrača neposredno k muslimanom z evangeljskim pričevanjem in oznanjevanjem evangelija. (Lehmann 2012, 552) V tem je prava novost asiškega ubožca, ki je tako začrtal nove smernice pri pojmovanju misijonske dejavnosti Cerkve.

\section{Sklep}

Veliko vrstic je bilo posvečenih namenu Frančiškovega obiska pri sultanu al-Malik al-Kamilu: je šlo za željo po mučeništvu, po spreobrnjenju sultana, po iskanju premirja med obema stranema ali preposto za željo po oznanjevanju evangeljskega miru? Večplastnost Frančiškove osebne izkušnje in reda manjših bratov je botrovala različnim interpretacijam tako pri Frančiškovih sodobnikih kakor še danes. A kot pravi Vauchez, morda niti ni tako pomembno, kaj se je resnično dogodilo med Frančiškom in sultanom tistega septembrskega dne 1219. Že dejstvo, da je do tega srečanja prišlo, prinaša s seboj veliko novost in pomembne posledice tudi za naprej. Na prvi pogled se zdi, da Frančišek s svojim obiskom pri sultanu ni veliko dosegel. A vendar lahko skupaj z nekaterimi avtorji domnevamo, da je morda vsaj posredno vplival na kasnejše dogodke, npr. na desetletno premirje, ki sta ga leta 1229 v Jafi sklenila egiptovski sultan al-Malik al-Kamil in rimsko-nemški cesar Friderik II. in s katerim so kristjani za nekaj časa ponovno dobili v roke nekatere svete kraje, med njimi tudi Božji grob. (Vauchez 2010, 98-99) Morda pa je omenjeno srečanje zasejalo tudi seme, ki je nosilo v sebi še daljnoročnejše posledice: dopustimo možnost, da je Frančišek pri sultanu in muslimanih pustil tak pozitiven vtis, da so zaradi tega Frančiškovi bratje lahko stoletja nemoteno, tudi v času, ko drugim katoliškim redovom in kongregacijam ni bilo dovoljeno, opravljali 
svoje delo na omenjenem ozemlju (Vauchez 2010, 101; Ajello 2011, 477). Morda je ravno v tem tisto največje "veliko dobro delo«, o katerem govori Ernoulova Kronika.

\section{Viri in reference}

Alberigo, Giuseppe, idr., ur. 2002.

Conciliorum Oecumenicorum Decreta.

2. izd. Bologna: Edizioni Dehoniane.

Bernardo il Tesoriere. 2004. La conquista della Terra Santa. Ernesto Caroli, ur. Fonti Francescane, Nuova edizione, Padova: Editrici Francescane: $2235-2237$.

Bonaventura iz Bagnoregia. 2004. Legenda maior/Legenda maggiore (LegM). Ernesto Caroli, ur. Fonti Francescane: 1020-1329.

Cronaca di Ernoul. 2004. Ernesto Caroli, ur. Fonti Francescane: 2231-2234.

Čelanski, Tomaž. 2004. Vita beati Francisci/ Vita del beato Francesco (1 Cel). Ernesto Caroli, ur. Fonti Francescane: 315-571.

- - - 2014. Življenje svetega Frančiška. Asiški vir 2. Ljubljana: Brat Frančišek.

I Fioretti di San Francesco. 2004. Ernesto Caroli, ur. Fonti Francescane: 1826-1958.

Ajello, Anna. 2011. I frati Minori e i Saraceni nel XIII secolo. Studi Francescani 108, 3-4: 477-491.

Annala, Pauli. 2003. Frate Francesco e la quinta crociata. Frate Francesco 69: 409-425.

Cardini, Franco. 2019. Francesco e il Sultano: la storia. San Francesco e il sultano. Ottocento anni di dialogo. Catalogo della mostra fotografica. Assisi: Sacro Convento di San Francesco: 37-40.

Frugoni, Chiara. 2011. Francesco e la prova del fuoco. Studi Francescani 108, 3-4: 525-536.
Jakob iz Vitryja. 2004. Lettera del 1220 sulla presa di Damiata (2 Vitry 2). Ernesto Caroli, ur. Fonti Francescane: 2210-2213.

- - -. 2004. L'Ordine e la predicazione dei frati minori, iz "Historia Occidentalis/ Orientalis" (Vitry Hoc). Ernesto Caroli, ur. Fonti Francescane: 2214-2230.

Jordan iz Giana. 2004. Cronaca (Kronika). Ernesto Caroli, ur. Fonti Francescane: 2320-2412.

Klaren, Angel. 2004. Libro delle cronache o delle tribolazioni. Ernesto Caroli, ur. 2004. Fonti Francescane: 2113-2199.

Ricordi di frate Illuminato. 2004. Ernesto Caroli, ur. Fonti Francescane: 2690-2691.

Storia di Eraclio. 2004. Ernesto Caroli, ur. Fonti Francescane: 2238.

Vodilo in življenje. Spisi sv. Frančiška in sv. Klare. 1998. Ljubljana: Slovenska kapucinska provinca.

Hoeberichts, Jan. 2002. Francesco e l'islam. Prev. Romeo Fabri. Padova: Edizioni Messaggero. Izvirnik, Franciscus en de Islam. Assen: Van Gorcum.

Jeusset, Gwendolé. 1996. Rencontre sur l'autre rive. François d'Assise et les Musulmans. Paris: Les Éditions Franciscaines.

Lehmann, Leonhard. 2012. Francesco incontra il sultano: l'inizio di una missione di pace. Studio comparativo delle più antiche fonti. Miscellanea Francescana 112: 504-556.

Ligato, Giuseppe. 2011. La crociata a Damietta tra legato papale, profezie e strategie. Studi Francescani 108: 427-476. 
Marini, Alfonso. 2012. Storia contestata: Francesco d'Assisi e l'Islam. Franciscana 14: 1-54.

Melone, Mary. 2011. Il desiderio di martirio di Francesco d'Assisi nella Legenda Maior di Bonaventura da Bagnoregio. Studi Francescani 108: 509-524.

Radi, Luciano. 2006. Francesco e il sultano. Assisi: Cittadella Editrice.

San Francesco e il sultano. Ottocento anni di dialogo. 2019. Catalogo della mostra fotografica. Assisi: Sacro Convento di San Francesco.

Sella, Pacifico. 2005. San Francesco e l'incontro con il Sultano d'Egitto. Rivisitazione storica per una rilettura dei rapporti con l'islam. Antonianum 80: 485-498.

- - -. 2011. Francesco e il Sultano: l'incontro. Studi Francescani 108: 493-507.
Tanner, Norman. 2013. Kratka zgodovina katoliške Cerkve. Prev. Bogdan Kolar. Ljubljana: Družina. Izvirnik, New Short History of the Catholic Church. London - New York: Burns \& Oates.

Tolan, John. 2011. History and memory: the encounter between Francis of Assisi and Malik al-Kâmil. Studi Francescani 108: 537-559.

Vauchez, André. 2010. San Francesco d'Assisi. Tra storia e memoria. Torino: Einaudi. Izvirnik, François d'Assise. Entre histoire et mémoire. Paris: Librairie Arthème Fayard.

Vítores González, Artemio. 2013. Francesco d'Assisi e la Terra Santa. Prev.

Giuseppe Staccone. Padova: Edizioni Messaggero. Izvirnik: Francisco de Asís y Tierra Santa. Boadilla del Monte (Madrid): PPC Editorial y Distribuidora SA. 